\title{
Rising CO2 from historical concentrations enhances the physiological performance of Brassica napus seedlings under optimal water supply but not under reduced water availability
}

by Faralli, M., Grove, I.G., Hare, M.C., Kettlewell, P.S. and Fiorani, F.

Copyright, Publisher and Additional Information: This is the author accepted manuscript. The final published version (version of record) is available online via Wiley Please refer to any applicable terms of use of the publisher.

DOI: $10.1111 /$ pce. 12868 
1 Rising $\mathrm{CO}_{2}$ from historical concentrations enhances the physiological

2 performance of Brassica napus seedlings under optimal water supply but not

3 under reduced water availability.

4 Michele Faralli ${ }^{1 *}$, Ivan G. Grove ${ }^{1}$, Martin C. Hare ${ }^{1}$, Peter S. Kettlewell ${ }^{1}$ \& Fabio

$5 \quad$ Fiorani $^{2}$

61 Department of Crop and Environment Sciences, Harper Adams University,

7 Newport, Shropshire, TF10 8NB, UK.

$8 \quad 2$ IBG-2: Plant Sciences, Forschungszentrum Jülich $\mathrm{GmbH}$, Jülich, Germany

9 *Correspondence: Michele Faralli, Harper Adams University, Newport, Shropshire,

10 TF10 8NB, UK. Email: mfaralli@harper-adams.ac.uk

11 Running title

12 Water stress at different $\left[\mathrm{CO}_{2}\right]$

13 Keyword index

14 Canola, elevated $\mathrm{CO}_{2}$, climate change, photosynthesis, stomatal conductance, shoot

15 biomass, leaf area, evapotranspiration

\section{Abstract}

17 The productivity of many important crops is significantly threatened by water 18 shortage and the elevated atmospheric $\mathrm{CO}_{2}$ can significantly interact with 19 physiological processes and crop responses to drought. We examined the effects of 20 three different $\mathrm{CO}_{2}$ concentrations (historical $\sim 300$ ppm, ambient $\sim 400$ ppm and 21 elevated $\sim 700 \mathrm{ppm}$ ) on physiological traits of oilseed rape (Brassica napus L.) seedlings subjected to well-watered and reduced water availability. Our data show i) 
23 that, as expected, increasing $\mathrm{CO}_{2}$ level positively modulates leaf photosynthetic traits, leaf water-use efficiency and growth under non-stressed conditions although a pronounced acclimation of photosynthesis to elevated $\mathrm{CO}_{2}$ occurred; ii) that the predicted elevated $\mathrm{CO}_{2}$ concentration does not reduce total evapotranspiration under drought when compared to the present (400 ppm) and historical (300 ppm) concentrations because of a larger leaf area that does not buffer transpiration; iii) that accordingly the physiological traits analysed decreased similarly under stress for all $\mathrm{CO}_{2}$ concentrations. Our data support the hypothesis that increasing $\mathrm{CO}_{2}$ concentrations may not significantly counteract the negative effect of increasing drought intensity on Brassica napus performance.

\section{Introduction}

The concentration of atmospheric $\mathrm{CO}_{2}\left(\left[\mathrm{CO}_{2}\right]\right)$ has been increasing steeply from 1958 ( 316 ppm) to 2016 (>400 ppm) (NOAA Mauna Loa Observatory, Hawaii) and the Intergovernmental Panel on Climate Change has predicted a $\left[\mathrm{CO}_{2}\right]$ in 2050 between $\sim 550$ and $\sim 700 \mathrm{ppm}$. From an agricultural point of view, the elevated $\left[\mathrm{CO}_{2}\right]$ has been related to direct effects on crops' physiological processes (Leakey et al. 2012). Indeed, $C_{3}$ crops (Fitzgerald et al. 2016; O'Leary et al. 2015) and, to a lesser extent $\mathrm{C}_{4}$ crops (Ruiz-Vera et al. 2015), exhibited i) higher photosynthetic rates due to an increased Rubisco carboxylation activity and a decreased oxygenation reaction; ii) a lower stomatal conductance $\left(g_{s}\right)$ following a depolarization of the membrane potential of the guard cells accompanied by an increase of the outward activity of $\mathrm{K}^{+}$channels and a subsequent increase in guard cell $\mathrm{Ca}^{2+}$ concentration (Leakey et al. 2012, Ainsworth \& Rogers, 2007). These physiological changes have been related to increasing biomass production and ameliorated responses of plants to drought by an improvement of water-use efficiency at the canopy level (Leakey et 
al. 2012). It is well-recognized that drought is the main factor affecting global crop production and food security (Cattivelli et al. 2008) and climate change is predicted to significantly increase the magnitude of water shortage and negatively affect the yield of crops (Parmesan \& Yohe, 2003). In this context, oilseed rape (OSR, Brassica napus L.) is becoming one of the most popular oilseed crops in the world. Drought periods over the most drought-sensitive phenological stages for OSR (anthesis until mid-pod development) can lead up to $40 \%$ of seed yield losses (Faralli et al. 2016).

It is therefore of pivotal importance to understand the physiological mechanisms that relate atmospheric $\mathrm{CO}_{2}$ to drought and to determine whether the expected detrimental effects on crops following the increases in extreme environmental conditions could be at least mitigated by increases in $\mathrm{CO}_{2}$ concentrations. A large amount of work showed positive effects of elevated atmospheric $\mathrm{CO}_{2}$ concentration on crop's drought tolerance and hence yield reduction mitigation (Baker et al. 1997; Wall 2001; Qaderi et al. 2006; O'Leary et al. 2015; Fitzgerald et al. 2016). However, experiments on OSR have shown that elevated $\mathrm{CO}_{2}$ concentrations may not mitigate the detrimental effects of increasing temperatures on yield (Frenck et al. 2011). In addition, Gray et al. (2016) have recently shown in multi-year FACE experiments that the improvements in physiological performance and yield of soybean from elevated $\left[\mathrm{CO}_{2}\right]$ can be counteracted by severe drought conditions. Therefore we conducted three experiments in the same controlled environment room at different $\mathrm{CO}_{2}$ concentrations ( 300 ppm - historical 1950/1960 [CO $]$, h[CO $]$; 400 ppm - ambient $\left[\mathrm{CO}_{2}\right], \mathrm{a}_{\mathrm{a}}\left[\mathrm{CO}_{2}\right] ; \sim 700 \mathrm{ppm}$ - elevated $\left.\left[\mathrm{CO}_{2}\right], \mathrm{e}\left[\mathrm{CO}_{2}\right]\right)$ and all three comparing the same combinations of watering regimes. The aims were to i) explore the physiological effects of these $\left[\mathrm{CO}_{2}\right]$ on winter OSR seedlings growth and development: ii) to 
evaluate the interactions between the different $\left[\mathrm{CO}_{2}\right]$ and drought; iii) to characterize and evaluate the relationships between physiological traits involved in the response of OSR to different $\left[\mathrm{CO}_{2}\right]$ and drought.

\section{Materials and methods}

\section{Plant materials and experimental layout}

Winter oilseed rape (OSR, Brassica napus L.) seeds (cv. Excalibur, Dekalb, UK) were sown on $8^{\text {th }}$ January 2016 for Experiment I，20 ${ }^{\text {th }}$ January 2016 for Experiment II, and $9^{\text {th }}$ February 2016 for Experiment III in individual pots (pot width $11 \mathrm{~cm}$, pot height $13 \mathrm{~cm}$, total volume $\left.\sim 1500 \mathrm{~cm}^{3}\right)$ containing the same amount $(650 \mathrm{~g}+25 \mathrm{~g}$ of pot weight) of a peat, sand, and pumice plant cultivation substrate (SoMi 513, Dachstauden; Hawita, Vechta, Germany) characterized with a water retention curve as described by Barboza-Barquero et al. (2015). Plants were germinated in a growth chamber at $20^{\circ} \mathrm{C}$ day $/ 15^{\circ} \mathrm{C}$ night, $12 / 12$ photoperiod, $60 \% \mathrm{RH}$ and ambinet $\left[\mathrm{CO}_{2}\right]$. PAR was provided by neon lamps at $\sim 200 \mu \mathrm{mol} \mathrm{m}^{-2} \mathrm{~s}^{-1}$ at shoot apex measured with a LI-190R PAR sensor (LI-COR, Lincoln, Nebraska USA). Plants were watered daily with rain water to maintain the optimum soil moisture conditions for plant germination and growth (around $90 \%$ of available water content, AWC, according to a water retention curve, as described in Barboza-Barquero et al., 2015). Three seeds were sown in each pot and for all the experiments two emerged seedlings were removed after 4 days from emergence. At the $2^{\text {nd }}$ leaf stage (GS $1.2 \mathrm{BBCH}$ growth scale, $19^{\text {th }}$ January for Experiment I, $7^{\text {th }}$ February for Experiment II and 25th February 2016 for Experiment III) seedlings were placed in a controlled environment chamber (Jülich Forschungszentrum, IBG-2 Plant Science, walk-in custom-made chamber) at $20^{\circ} \mathrm{C}$ day $/ 15^{\circ} \mathrm{C}$ night, $16 / 8$ photoperiod, $60 \% \mathrm{RH}$ and a VPD of $0.94 \mathrm{kPa}$. PAR was 
97 provided with HPI-T-plus lamps (400W/645 E40, Philips, Netherlands) at an average of $\sim 500 \mu \mathrm{mol} \mathrm{m} \mathrm{s}^{-2}$ at plant level with a minimum value of $460 \mu \mathrm{mol} \mathrm{m} \mathrm{m}^{-2} \mathrm{~s}^{-1}$ and a maximum of $540 \mu \mathrm{mol} \mathrm{m} \mathrm{m}^{-2} \mathrm{~s}^{-1}$.

Each experiment consisted of five randomized blocks with two treatments (wellwatered - WW and droughted - WS) and six replicates in each block. Treatments were applied when plants reached the $4^{\text {th }}$ leaf stage based on visual observations (GS 1.4, BBCH oilseed rape growth scale) (days after treatment 0 , DAT $0-25^{\text {th }}$ January for Experiment I, $12^{\text {th }}$ February for Experiment II and $1^{\text {st }}$ March 2016 for Experiment III).

According to the soil retention curve of the SoMi substrate, target weight at "pot capacity" (100\% of available water content) was set to $1070 \mathrm{~g}$ of pot weight (including $25 \mathrm{~g}$ of pot weight and $20 \mathrm{~g}$ of plant fresh weight at the 4th leaf stage ) and the permanent wilting point was set at $600 \mathrm{~g}$. Thus the total AWC of the pots was accounted to be $425 \mathrm{ml}$. Hence, well-watered pots (WW, $\mathrm{n}=6$ ) were weighed daily with a MC1 balance (Sartorius, Göttingen, Germany) and then rewatered to avoid any decrease in soil moisture according to the equation:

Eqn (1) Water to add = "pot capacity" weight - pot weight

Watering was withheld to water stressed pots (WS) over the whole experimental period (12 days). Pot saucers were used to avoid any water uptake. Total daily pot evapotranspiration (ET) was calculated as the water to add for WW and the daily reduction in pot weight for WS.

For each individual experiment, the chamber was set at a different $\left[\mathrm{CO}_{2}\right]$ : Experiment I 400 ppm, a $\left[\mathrm{CO}_{2}\right]$; Experiment II 700 ppm, e[ $\left[\mathrm{CO}_{2}\right]$; and Experiment III 300 ppm, ${ }_{n}\left[\mathrm{CO}_{2}\right]$. A respirator (Fig. S1) made up of a tube connected with a plastic mask on one side (respirator) was developed and used in the growth chamber to avoid 
undesired $\left[\mathrm{CO}_{2}\right]$ fluctuations due to experimenter breathing during data collection and plant manipulation. The average $\left[\mathrm{CO}_{2}\right]$ for each experiment was $402.6 \pm 10.1$ (SD) for Experiment I, $700.9 \pm 9.7$ for Experiment II and $285.5 \pm 14.3$ for Experiment III (Fig. S2)

\section{Growth and relative water content analysis}

On DAT 1, 4, 8 and 12, plants $(n=6)$ from each treatment were harvested for all the experiments. RWC was calculated according to Barr \& Weatherley (1962) and was determined as described by Faralli et al. (2015). Briefly, between 12:00 and 13:00, one piece of leaf tissue of the fourth leaf $\left(\sim 2 \mathrm{~cm}^{2}\right)$ was collected using a scalpel for each plant $(n=6)$. These samples were collected in a central region of the lamina between the main vein and the leaf margin avoiding lateral veins. The fresh weight was then recorded $\left(\mathrm{FW}_{\mathrm{W}}\right)$ and the samples were soaked in distilled water in Petri dishes in the dark and at $\sim 4^{\circ} \mathrm{C}$ during four hours. The turgid weight ( $\left.T_{w}\right)$ was recorded, the dried disks (oven-dried at $80^{\circ} \mathrm{C}$ for 24 hours) were weighed the day after, and the dry weight was recorded (Dw). RWC (\%) was then calculated according to:

Eqn (2) $\operatorname{RWC}(\%)=\frac{\mathrm{FW}_{\mathrm{W}}-\mathrm{D}_{\mathrm{W}}}{\mathrm{T}_{\mathrm{W}}-\mathrm{D}_{\mathrm{W}}} \times 100$

After that, leaf number (LN) was counted and plants were excised at the base of the stem and leaf and stem fresh weight were recorded (Mettler Toledo XS 205 Dual Range, Columbus, USA). Total leaf area (LA) was recorded with a leaf area meter (LI-3100C area meter, Li-Cor, Lincoln, NE, USA). Samples were dried in an oven (Nabertherm P330, Nabertherm GmbH Lilienthal/Bremen, Germany) over 24 hours at $65^{\circ} \mathrm{C}$ and leaf, stem and total shoot dry weight were recorded. Specific leaf area was calculated as: SLA $\left(\mathrm{g} \mathrm{m}^{-2}\right)=$ leaf area / leaf DW. 
147 Gas-exchange and chlorophyll fluorescence were simultaneously measured with a 148 Li-Cor 6400 (Li-Cor, Lincoln, NE, USA) with an integrated fluorescence leaf cuvette 149 (LI-6400-40; Li-Cor) on DAT 1, 4, 8 and 12 for all the experiments, between 09:00 and 12:00. To minimize potential leaf position and developmental age effects, all the gas-exchange measurements were taken on the $4^{\text {th }}$ fully expanded leaf of six randomly selected plants for each treatment. In the Li-Cor cuvette, all the parameters (leaf $\mathrm{CO}_{2}$ assimilation at saturating light - $A_{\max }$, stomatal conductance $-g_{s}$ and the ratio between sub-stomatal $\mathrm{CO}_{2}$ and the ambient $\left[\mathrm{CO}_{2}\right]-\mathrm{C}_{\mathrm{i}} / \mathrm{C}_{\mathrm{a}}$ ) were collected at 400 ppm $\mathrm{CO}_{2}$ (Experiment I), 700 ppm CO (Experiment II) and 300 ppm $\mathrm{CO}_{2}$ (Experiment III). Cuvette temperature was maintained at $25^{\circ} \mathrm{C}$, photosynthetically active photon flux density (PPFD) was $1200 \mu \mathrm{mol} \mathrm{m} \mathrm{m}^{-2} \mathrm{~s}^{-1}$ (saturating PPFD for OSR seedlings, previously evaluated by light curves, Fig. S3), with a 10:90 blue:red light and a flow rate of $300 \mu \mathrm{mol} \mathrm{s} \mathrm{s}^{-1}$. Intrinsic water-use efficiency was calculated as $A_{\max } / g_{s}$. The ratio $\left(A_{\max } / g_{s}\right)$ is considered to be more reliable than the water-use efficiency calculated from $\mathrm{CO}_{2}$ assimilation to transpiration rate, since it is not affected by the VPD inside the leaf chamber (Webster et al. 2016). The data were collected after the leaf achieved a steady-state. The data were collected after the leaf achieved a steady-state, and minimum fluorescence $\left(F_{s}\right)$ and maximum fluorescence $\left(F_{m}\right)$ were recorded by ensuring a light-saturating pulse of $8000 \mu \mathrm{mol}$ $\mathrm{m}^{-2} \mathrm{~s}^{-1}$. The actual photochemical efficiency of the photosystem II $\left(\Delta F / F_{m}\right)$ was calculated according to Baker (2008) as follow:

$$
\text { Eqn (3) } \Delta \mathrm{F} / \mathrm{Fm}^{\prime}=\frac{\mathrm{Fm} \mathrm{m}^{\prime}-\mathrm{Fs}}{\mathrm{Fm} \mathrm{m}^{\prime}}
$$

and the electron transport rate as: 


\section{Statistical analysis}

172 Available water content and daily evapotranspiration data from the three experiments 173 are daily means $(n=6) \pm$ standard error (SE). Carbon dioxide treatments are means $174(n=1440) \pm$ standard deviation (SD). With the exception of $\left[\mathrm{CO}_{2}\right]$, the parameters inside the growth chamber (i.e. $\mathrm{RH}$, temperature, light and VPD) were very similar or identical during the three experiments. Also, since the growth conditions of the three experiments were very similar and no morphological differences were recorded between the three sets of plant material, a hypothetical time-specific effect affecting the $\mathrm{CO}_{2}$ treatments was not considered a possibility. Therefore all the physiological traits were analysed with a two-way ANOVA $\left(\mathrm{CO}_{2} \times\right.$ watering regimes, Figure $\left.\mathrm{S} 4\right)$ in GenStat $17^{\text {th }}$ Edition (VSN International, UK). However, since the three experiments were formally independent, the homogeneity of variance for each two-way ANOVA was checked by visually examining the distribution histogram of the residuals and the fitted vs. residuals plot. While the distribution was acceptable for all the traits and DAT, in five cases (RWC DAT 12, Leaf Area DAT 8, Amax DAT 12, Amax $/ g_{s}$ DAT 1) the fitted vs. residuals plot showed heteroscedasticity. These data were transformed to a natural logarithmic scale and in all cases the heteroscedasticity was reduced and the distribution was improved. Subsequently the log-transformed data were subjected to two-way ANOVA and the $P$-values for all the interactions were recorded. In all the cases logarithmic transformation had a negligible effect on $P$ values suggesting that the data heteroscedasticity was not significantly affecting the data. Therefore, due to the above evidence, the data are statistically analysed and presented in their original form without logarithmic transformation and thus including 
194

195

196

197

198

199

200

201

202

203

204

205

206

207

208

209

210

211

212

213

214

215

216

$\left[\mathrm{CO}_{2}\right]$ factor in the ANOVA model. The two-way ANOVA outputs are presented in Supplementary Fig. 4.

\section{Results}

\section{Total plant evapotranspiration and pot available water content}

Total plant ET of WW was similar at each $\left[\mathrm{CO}_{2}\right]$, increasing from $\sim 50 \mathrm{~mL}$ at DAT 1 to $\sim 130 \mathrm{~mL}$ at DAT 7 (Fig. 1 A). From DAT 8, while ${ }_{\mathrm{h}}\left[\mathrm{CO}_{2}\right]$ maintained total $\mathrm{ET}$ at $\sim 180$ $\mathrm{mL}$, the plants grown under ${ }_{\mathrm{a}}\left[\mathrm{CO}_{2}\right]$, slightly decreased the $\mathrm{ET}$ from $\sim 160 \mathrm{~mL}$ to $\sim 120$ $\mathrm{mL}$. On the contrary, e[ $\left.\mathrm{CO}_{2}\right]$, steadily maintained a significant lower ET value from $\sim 100 \mathrm{ml}$ at DAT 8 to $\sim 60 \mathrm{~mL}$ at DAT 12. Therefore, pot AWC of WW plants from DAT 8 to DAT 12 was higher in ${ }_{\mathrm{e}}\left[\mathrm{CO}_{2}\right]$ conditions than under ${ }_{\mathrm{a}}\left[\mathrm{CO}_{2}\right]$ and, to a greater extent, $h\left[\mathrm{CO}_{2}\right]$ (Fig. 1B). WS treatment decreased both ET and AWC. Under WS conditions, $\mathrm{e}\left[\mathrm{CO}_{2}\right]$ plants showed a significantly higher ET when compared to ${ }_{a}\left[\mathrm{CO}_{2}\right]$ and ${ }_{\mathrm{h}}\left[\mathrm{CO}_{2}\right]$ but only until DAT4 (Fig. $1 \mathrm{C}$ ). From DAT 5, similar decreases in ET were recorded between $\left[\mathrm{CO}_{2}\right]$. Therefore, pot AWC of WS plants was lower under $\left[\mathrm{CO}_{2}\right]$ than under ${ }_{a}\left[\mathrm{CO}_{2}\right]$ and ${ }_{h}\left[\mathrm{CO}_{2}\right]$, although PWP was reached similarly for all the $\left[\mathrm{CO}_{2}\right]$ between DAT 7 and DAT 8 (Fig. 1D).

\section{Growth analysis}

Leaf number (LN) significantly increased over time in WW plants grown at all the $\left[\mathrm{CO}_{2}\right]$ (from 4 leaves at DAT 1 to $7.5-8$ leaves at DAT 12) and no significant differences were found between the different $\left[\mathrm{CO}_{2}\right]$ treatments (Fig. $2 \mathrm{~A}$ ). WS significantly decreased LN compared to the WW plants when grown at ${ }_{h}\left[\mathrm{CO}_{2}\right]$ and ${ }_{a}\left[\mathrm{CO}_{2}\right]$ since DAT 4 (Fig. $2 \mathrm{~B}$ ). However ${ }_{\mathrm{e}}\left[\mathrm{CO}_{2}\right]$ showed a reduction in $\mathrm{LN}$ under WS only from DAT 8. 
217 Over the twelve days of the experiments, WW plants grown in ${ }_{a}\left[\mathrm{CO}_{2}\right]$ had a shoot

218 DW (Fig. 2C) that was significantly higher than that of the plants grown in ${ }_{h}\left[\mathrm{CO}_{2}\right]$ by

219

220

221

222

223

224

225

226

227

228

229

230

231

232

233

234

235

236

237

238

239

240

241 $34 \%$ on average (Fig. 2C) $(P<0.001$ for DAT 4, 8 and 12). Increases in shoot DW of $20 \%$ on average were observed in plants grown at $\left[\mathrm{CO}_{2}\right]$ (Fig. $2 \mathrm{C}$ ) with respect to the plants grown under ${ }_{a}\left[\mathrm{CO}_{2}\right]$. Significant reductions in shoot DW were observed under WS on DAT 8 and DAT 12 at all the $\left[\mathrm{CO}_{2}\right]$ when compared to the WW plants (Fig. 2D). However, WS plants grown under e $\left[\mathrm{CO}_{2}\right]$ exhibited a higher DW compared to $\mathrm{h}_{[}\left[\mathrm{CO}_{2}\right]$ and ${ }_{\mathrm{a}}\left[\mathrm{CO}_{2}\right]$ by $42 \%$ and $33 \%$ on DAT $4,40 \%$ and $26 \%$ on DAT 8 and $37 \%$ and $27 \%$ on DAT 12 , respectively .

Leaf area (LA) of WW plants grown under ${ }_{a}\left[\mathrm{CO}_{2}\right]$ significantly increased with time from $190 \mathrm{~cm}^{2}$ on DAT 1 to $800 \mathrm{~cm}^{2}$ on DAT 12 (Fig. 2E). Under ${ }_{h}\left[\mathrm{CO}_{2}\right]$, WW plants exhibited a similar significant increase in LA that was however lower than that of the plants grown at ${ }_{a}\left[\mathrm{CO}_{2}\right]$ (Fig. 2E) (from $190 \mathrm{~cm}^{2}$ on DAT 1 to $590 \mathrm{~cm}^{2}$ on DAT 12). e[CO $\left[\mathrm{CO}_{2}\right]$ stimulated LA of WW plants leading to an average LA of $1190 \mathrm{~cm}^{2}$ on DAT 12 (Fig. 2E). For DAT 4 and DAT 8, however, no significant differences in LA were found between plants grown at ${ }_{e}\left[\mathrm{CO}_{2}\right]$ and ${ }_{a}\left[\mathrm{CO}_{2}\right]$. WS had a significant effect on $\mathrm{LA}$ at all the $\left[\mathrm{CO}_{2}\right]$ and the decrease was significant since DAT 4 in e $\left[\mathrm{CO}_{2}\right],{ }_{a}\left[\mathrm{CO}_{2}\right]$ and $\mathrm{h}\left[\mathrm{CO}_{2}\right]$-grown plants (Fig. $\left.2 \mathrm{~F}\right)$.

Specific leaf area (SLA) decreased over time on WW plants grown at all the $\left[\mathrm{CO}_{2}\right]$ and WS significantly decreased SLA values at all the $\left[\mathrm{CO}_{2}\right](P<0.001$ since DAT 4) (Fig. 2G and $\mathrm{H}$ ).

\section{Plant water status}

The leaf RWC of WW plants fluctuated from $90 \%$ to $91 \%$ on average and no significant differences were observed between the three $\left[\mathrm{CO}_{2}\right]($ Table 1$)$. Under WS conditions, leaf RWC significantly decreased from DAT 4 at all the $\left[\mathrm{CO}_{2}\right](P<0.001$ at 
242 all the DAT). RWC of ${ }^{[}\left[\mathrm{CO}_{2}\right]$ plants under WS conditions was significantly higher

243 (RWC 70\%, P=0.016) than ${ }_{a}\left[\mathrm{CO}_{2}\right]$ (RWC 62\%) and $\mathrm{h}_{\mathrm{h}}\left[\mathrm{CO}_{2}\right](\mathrm{RWC} 67 \%)$ at DAT 8.

244

245

246

247

248

249

250

251

252

253

254

255

256

257

258

259

260

261

262

263

264

265

266

However, since the drop in RWC was similar for all the other DAT, RWC values were not overall significantly different under WS between $\left[\mathrm{CO}_{2}\right]$ leading to very similar values at DAT 12.

\section{Gas-exchange}

WW plants grown under ${ }_{a}\left[\mathrm{CO}_{2}\right]$ showed an average $A_{\max }$ of $26 \mu \mathrm{mol} \mathrm{m}{ }^{-2} \mathrm{~s}^{-1}$ that was $22 \%$ lower than that of the plants grown in ${ }_{e}\left[\mathrm{CO}_{2}\right]$ (Fig. $\left.3 \mathrm{~A}\right)$. On the contrary, ${ }^{[}\left[\mathrm{CO}_{2}\right]$ exhibited an increase in $A_{\max }$ by $12 \%$ on average with respect to the ${ }_{h}\left[\mathrm{CO}_{2}\right]$ (Fig. $3 A$ ). Plants under WS conditions exhibited a reduction in $A_{\max }$ compared to the WW plants that was significant from DAT 4 for all the $\left[\mathrm{CO}_{2}\right](P<0.001)$ (Fig. 3B).

WW plants grown under ${ }_{a}\left[\mathrm{CO}_{2}\right]$ exhibited a $g_{s}$ of $0.67 \mathrm{~mol} \mathrm{~mm}^{-2} \mathrm{~s}^{-1}$ on average, showing a decreasing slope over the last days of the experiment (Fig. 3C). With respect to the ${ }_{a}\left[\mathrm{CO}_{2}\right]$, a $7 \%$ increase on average in $g_{s}$ was observed in ${ }_{h}\left[\mathrm{CO}_{2}\right]-$ grown plants (Fig. 3C), without showing any $g_{s}$ reduction over time. On the contrary, $g_{s}$ was significantly reduced over time in ${ }_{\mathrm{e}}\left[\mathrm{CO}_{2}\right]$ plants and by $40 \%$ on average with respect to the ${ }_{a}\left[\mathrm{CO}_{2}\right]$ (Fig. $3 \mathrm{C}$ ). WS conditions reduced $g_{s}$ by $64 \%, 55 \%$ and $40 \%$ under h[$\left[\mathrm{CO}_{2}\right],{ }_{\mathrm{a}}\left[\mathrm{CO}_{2}\right]$ and $\left[\mathrm{CO} \mathrm{CO}_{2}\right]$ respectively (Fig. 3D).

WW plants grown under $\mathrm{h}\left[\mathrm{CO}_{2}\right]$ and ${ }_{\mathrm{a}}\left[\mathrm{CO}_{2}\right]$ showed a relatively stable $\mathrm{A}_{\max } / g_{s}$ over time with an average value of $31 \mu \mathrm{mol} \mathrm{mol}^{-1}$ and $40 \mu \mathrm{mol} \mathrm{mol} \mathrm{m}^{-1}$ respectively (Fig. $3 E)$. On the contrary, e $\left[\mathrm{CO}_{2}\right]-$ grown plants showed a significant increase in time from DAT 1 to DAT 12 leading to an average value of $90 \mu \mathrm{mol} \mathrm{mol}{ }^{-1}$ (Fig. 3E). WS plants had higher $A_{\max } / g_{s}$ values with respect to the WW ones, with an average of 52,76 and $95 \mu \mathrm{mol} \mathrm{mol}^{-1}$ for ${ }_{h}\left[\mathrm{CO}_{2}\right],{ }_{a}\left[\mathrm{CO}_{2}\right]$ and ${ }_{\mathrm{e}}\left[\mathrm{CO}_{2}\right]$-grown plants respectively (Fig. $3 \mathrm{~F}$ ). Under WW conditions, ETR values of ${ }_{e}\left[\mathrm{CO}_{2}\right]$-grown plants was on average higher 
$\left(190 \mu \mathrm{mol} \mathrm{e} \mathrm{e}^{-1} \mathrm{~m}^{-2} \mathrm{~s}^{-1}\right)$ than $\mathrm{h}_{\mathrm{C}}\left[\mathrm{CO}_{2}\right]$ and ${ }_{\mathrm{a}}\left[\mathrm{CO}_{2}\right]\left(177\right.$ and $182190 \mu \mathrm{mol} \mathrm{e}^{-1} \mathrm{~m}^{-2} \mathrm{~s}^{-1}$ respectively) until DAT 8. Conversely, on DAT 12, similar ETR values were recorded between $\mathrm{h}\left[\mathrm{CO}_{2}\right]$ and ${ }_{\mathrm{a}}\left[\mathrm{CO}_{2}\right]\left(171\right.$ and $164 \mu \mathrm{mol} \mathrm{e}^{-1} \mathrm{~m}^{-2} \mathrm{~s}^{-1}$ respectively) that were lower compared to the ${ }_{\mathrm{e}}\left[\mathrm{CO}_{2}\right]\left(154 \mu \mathrm{mol} \mathrm{e}^{-1} \mathrm{~m}^{-2} \mathrm{~s}^{-1}\right)$. Under WS, declines in ETR values were evident for all the $\left[\mathrm{CO}_{2}\right]$ and although similar values were recorded at

DAT 12, the reduction was less pronounced under $\left[\mathrm{CO}_{2}\right]$ at DAT 8.

\section{Discussion}

$\left[\mathrm{CO}_{2}\right]$ influenced biomass accumulation and leaf gas-exchange under WW conditions

In our experiments, e[CO 2$]$ at 700 ppm stimulated $\mathrm{A}_{\max }$ by $\sim 22 \%$ (in line with the findings of Qaderi et al. (2006)) and $h_{[}\left[\mathrm{CO}_{2}\right]$ reduced $A_{\max }$ by $\sim 12 \%$ when both compared to ${ }_{a}\left[\mathrm{CO}_{2}\right]$ under WW conditions. The increase under ${ }_{e}\left[\mathrm{CO}_{2}\right]$ found in OSR seedlings was however lower than in other $C_{3}$ crops such as durum wheat ( 37\%; Aranjuelo et al. 2015) and rice ( 40\%, Vu et al. 1997) and in our experiments at DAT 12 the $A_{\max }$ of ${ }_{e}\left[\mathrm{CO}_{2}\right]$ plants was similar to that of ${ }_{a}\left[\mathrm{CO}_{2}\right]$. This suggests strong photosynthetic acclimation potentially due to the increased $L A$ of plants at ${ }_{e}\left[\mathrm{CO}_{2}\right]$ that lead to a reduction in Rubisco activity due to a depression in area-based leaf $\mathrm{N}$ content. In addition, the concomitant decrease in ETR and $A_{\max }$ that occurred under e $\left[\mathrm{CO}_{2}\right]$ but not under ${ }_{\mathrm{h}}\left[\mathrm{CO}_{2}\right]$ and ${ }_{a}\left[\mathrm{CO}_{2}\right]$ at DAT 12 can be also an indication of signals derived from increases in sucrose transport to guard cells (Outlaw, 2003), thylakoid membrane damage (Haworth et al. 2016) and/or increase in soluble sugar in the apoplast that reduced the mesophyll signal (Haworth et al. 2016).

The initial enhanced $A_{\max }$ following the increasing $\left[\mathrm{CO}_{2}\right]$ was accompanied by larger LA and shoot DW, consistent with previous work in OSR (Qaderi et al. 2006). This 
291 report however is the first showing differences in $A_{\max }$, LA and shoot DW between

292

293

294

295

296

297

298

299

300

301

302

303

304

305

306

307

308

309

310

311

312

313

314

315

${ }_{a}\left[\mathrm{CO}_{2}\right]$ and ${ }_{n}\left[\mathrm{CO}_{2}\right]$-grown OSR. It is not clear whether increased $A_{\max }$ following high $\left[\mathrm{CO}_{2}\right]$ can enhance sink activity but carbohydrate translocation can be reduced when sink size is limited (Arp, 1991). A FACE experiment with spring canola grown at 500 ppm $\left[\mathrm{CO}_{2}\right]$ showed no significant increases in yield compared to the ambient concentration-grown plots (Franzaring et al. 2008) probably due to limited carbon storage structures, therefore a potential small sink size (Reekie et al. 1998). Our data however indicate that OSR was potentially source-limited in the first years of its agricultural production $(\sim 1960)$ and that rising $\left[\mathrm{CO}_{2}\right]$ may have played a role at boosting the steady increase in OSR seed yield seen in recent years (Berry and Spink, 2006).

It has been proposed that the larger plant size that can be achieved at elevated $\mathrm{CO}_{2}$ is related to higher water use (hence transpiration) (Xu et al. 2013; Polley et al. 2008; Nowak et al. 2004). Our results show that in OSR seedlings grown under WW conditions the standardized transpiration over time for $L A$ is increased under ${ }_{a}\left[\mathrm{CO}_{2}\right]$ (1106 $\pm 105 \mathrm{mmol} \mathrm{H}_{2} \mathrm{O}$ ) when compared to the ${ }_{h}\left[\mathrm{CO}_{2}\right]\left(713 \pm 105 \mathrm{mmol} \mathrm{H}_{2} \mathrm{O}\right)$, but not under ${ }_{\mathrm{e}}\left[\mathrm{CO}_{2}\right]\left(852 \pm 105 \mathrm{mmol} \mathrm{H}_{2} \mathrm{O}\right)$ suggesting that the short-term acclimation to e $\left[\mathrm{CO}_{2}\right]$ is highly beneficial in the WW plants even if the $L A$ is dramatically increased. In addition, ET data show that from DAT 8, e[ $\left[\mathrm{CO}_{2}\right]$ plants are subjected to a significant reduction in water loss, potentially due to the larger leaf area that attenuates soil evaporation. This confirms that, although plant water loss and LA are not linearly correlated, larger LA can buffer the greater areas devoted to transpiration when self-shading and/or elevated leaf-area index threshold are reached under nonstressed conditions.

$\left[\mathrm{CO}_{2}\right]$ did not affect the whole-plant response under WS conditions. 
In our experiments, RWC of WS plants was on average 89, 80, 66 and $54 \%$, that reflects a good range of dehydration. When RWC was decreased to $66 \%$ (DAT 8), $g_{s}$ was completely inhibited at all the $\left[\mathrm{CO}_{2}\right]$, in line with previous findings (Albert et al. 2012). These data suggest application of mild stress at DAT 4 , severe stress at DAT

8 and terminal stress at DAT 12. We hypothesized that by maintaining low $g_{s}$, elevated atmospheric $\left[\mathrm{CO}_{2}\right]$ may ameliorate plant water status under stress by preserving soil water content (Leakey et al. 2012). Polley et al. (1999) suggested that the effects of elevated $\left[\mathrm{CO}_{2}\right]$ on osmotic adjustment are minimal, indicating that the maintenance of high plant water status in plants grown at elevated $\left[\mathrm{CO}_{2}\right]$ under stress is a result of stomatal control. However, and contrary to expectation, in our experiments no differences were found in $\mathrm{RWC}$ between $\left[\mathrm{CO}_{2}\right]$ treatments. In our experiments the larger leaf area produced under ${ }_{e}\left[\mathrm{CO}_{2}\right]$ led to a similar transpiration rate standardized for the $\mathrm{LA}\left(\sim 200 \mathrm{mmol} \mathrm{m}^{-2} \mathrm{~s}^{-1}\right.$ for all the $\left[\mathrm{CO}_{2}\right]$ under stress $)$ thus offsetting the water-loss reduction following the $\left[\mathrm{CO}_{2}\right]$-induced stomatal closure.

Recently Gray et al. (2016) showed that, at field level, elevated atmospheric $\mathrm{CO}_{2}$ concentration (from 550 to $585 \mathrm{ppm}$ ) does not always conserve water in soil following reduction in transpiration rate. This leads to non-significant benefits in terms of soybean yield when drought progressively increases. Since the relation between the increase in LA and transpiration in the field is not linear due to the selfshading effect that occur when large LA are reached, Gray et al. (2016) hypothesised that in wet years (large baseline $L A$ ), higher atmospheric $\left[\mathrm{CO}_{2}\right]$ may significantly reduce crop WU, consistently with our WW data on OSR (as explained above). However this may not occur in dry years, where increases in LA may only lead to higher plant water loss, similarly to our findings on WS. To confirm that, in our experiments $A_{\max }$-to- $g_{s}$ curves show that in the first part of soil drying, $g_{s}$ is reduced 
more than $A_{\max }$ leading to higher $A_{\max } / g_{s}$ values for all the $\left[\mathrm{CO}_{2}\right]$ treatments (Fig. $\left.4 \mathrm{~A}\right)$.

342 However, despite the curve plateau being higher at $\left[\mathrm{CO}_{2}\right]$, the shape of the $A_{\max }$-to$g_{s}$ curves were similar for all the $\left[\mathrm{CO}_{2}\right]$, possibly because the increased LA resulted in similar detrimental effects on $A_{\max }$ and RWC (Fig. 4B), thus similarly reducing $g_{s}$ (Fig. $4 \mathrm{C}$ ), between the $\left[\mathrm{CO}_{2}\right]$ under stress. This hypothesis is confirmed by ET data where ${ }_{e}\left[\mathrm{CO}_{2}\right]$ plants exhibited a very high ET from DAT 1 to DAT 4 due to higher LA and $L N$ that lead to fast use of the water resources available. Therefore, although leaf traits collected with gas-exchange system (e.g $A_{\max }$ and $A_{\max } / g_{s}$ ) were higher on

DAT 4 (therefore under a moderate stress) under ${ }_{\mathrm{e}}\left[\mathrm{CO}_{2}\right]$, increasing drought intensity leads to similar detrimental effects on OSR physiology regardless of the $\left[\mathrm{CO}_{2}\right]$ at which they are grown.

\section{Conclusions}

The work presented here shows improvements in the physiological performance of winter OSR seedlings in elevated $\left[\mathrm{CO}_{2}\right]$, mainly by stimulating photosynthesis and thus increasing leaf area in line with work focusing in other major food crops. Strong differences were found between plants grown at 300 and 400 ppm suggesting that OSR may have been significantly source-limited in the first years of its agricultural production ( 1960). Increasing the $\left[\mathrm{CO}_{2}\right]$ decreased leaf stomatal conductance and improve leaf water-use efficiency but no significant beneficial effects were found under drought due to the larger leaf area gained over the first few days of stress (when water was available) that offsets the elevated $\left[\mathrm{CO}_{2}\right]$-induced stomatal closure leading to similar total ET between the $\left[\mathrm{CO}_{2}\right]$ treatments. Our data are in line with recent findings in field-grown soybean, and shows this behaviour on another crop species and over a much broader range of $\left[\mathrm{CO}_{2}\right]$. 
This work was supported by the COST Action FA1306 'The quest for tolerant varieties - Phenotyping at plant and cellular level' through a short-term scientific mission awarded to MF for conducting all the experiments described in this paper at the Forschungszentrum Jülich, IBG-2 Plant Science. The additional funding support of Harper Adams University and John Oldacre Foundation is acknowledged. Thomas Bodewein (IBG-2) is thanked for the precious and continuous help throughout the experimental period as well as Olaf Gardeick, Thomas Hombach and Beate Uhlig. Dr Siegfried Jahnke's advice and help is acknowledged for the development of a custom-made respirator, and Dr Onno Muller for the helpful discussions about the use of gas-exchange systems. The authors declare no conflict of interests.

\section{References}

Ainsworth E. A., \& Rogers, A. (2007) The response of photosynthesis and stomatal conductance to rising $\left[\mathrm{CO}_{2}\right]$ : mechanisms and environmental interactions. Plant, cell

Albert B., Le Cahérec F., Niogret M.F., Faes P., Avice J.C., Leport L., \& Bouchereau, A. (2012) Nitrogen availability impacts oilseed rape (Brassica napus L.) plant water status and proline production efficiency under water-limited conditions. Planta 236, 659-676.

Aranjuelo I., Erice G., Sanz-Sáez A., Abadie C., Gilard F., Gil-Quintana E., ... \& Bourguignon J. (2015) Differential $\mathrm{CO}_{2}$ effect on primary carbon metabolism of flag leaves in durum wheat (Triticum durum Desf.). Plant, cell \& environment 38, 27802794.

Arp W.J. (1991) Effects of source-sink relations on photosynthetic acclimation to elevated $\mathrm{CO}_{2}$. Plant, Cell \& Environment 14, 869-875.

Baker J., Hartwell Allen L., Boote K., \& Pickering N. (1997) Rice responses to drought under carbon dioxide enrichment. 1. Growth and yield. Global Change Biology 3, 119-128.

Barboza-Barquero L., Nagel K. A., Jansen M., Klasen J. R., Kastenholz B., Braun S., ... \& Fiorani F. (2015) Phenotype of Arabidopsis thaliana semi-dwarfs with deep roots and high growth rates under water-limiting conditions is independent of the GA5 loss-of-function alleles. Annals of botany 116, 321-331. 
Barr H. D., \& Weatherley P. E. (1962) A re-examination of the relative turgidity technique for estimating water deficit in leaves. Australian Journal of Biological Sciences 15, 413-428.

Berry P.M., \& Spink J.H. (2006) A physiological analysis of oilseed rape yields: past and future. The Journal of Agricultural Science 144, 381-392.

Cattivelli L., Rizza F., Badeck F. W., Mazzucotelli E., Mastrangelo A. M., Francia, E., ... \& Stanca A. M. (2008) Drought tolerance improvement in crop plants: an integrated view from breeding to genomics. Field Crops Research 105, 1-14.

Faralli M., Grove I., Hare M., Boyle R., Williams K., Corke F., \& Kettlewell P. (2016) Canopy application of film antitranspirants over the reproductive phase enhances yield and yield-related physiological traits of water stressed oilseed rape (Brassica napus L.). Crop and Pasture Science 67, 751-765

Faralli M., Lektemur C., Rosellini D., \& Gürel F. (2015) Effects of heat shock and salinity on barley growth and stress-related gene transcription. Biologia Plantarum 59, 537-546.

Fitzgerald G. J., Tausz M., O'Leary G., Mollah M. R., Tausz-Posch S., Seneweera S., ... \& Norton R. M. (2016) Elevated atmospheric $\left[\mathrm{CO}_{2}\right]$ can dramatically increase wheat yields in semi-arid environments and buffer against heat waves. Global change biology 22, 2269-2284.

Franzaring J., Högy P., \& Fangmeier A. (2008) Effects of free-air $\mathrm{CO}_{2}$ enrichment on the growth of summer oilseed rape (Brassica napus cv. Campino). Agriculture, ecosystems \& environment 128, 127-134.

Frenck G., van der Linden L., Mikkelsen T.N., Brix H., \& Jørgensen R.B. (2011) Increased $\left[\mathrm{CO}_{2}\right]$ does not compensate for negative effects on yield caused by higher temperature and $\left[\mathrm{O}_{3}\right]$ in Brassica napus L. European Journal of Agronomy 35, 127134.

Gray S.B., Dermody O., Klein S.P., Locke A.M., McGrath J.M., Paul R.E., ... \& Ainsworth E.A. (2016) Intensifying drought eliminates the expected benefits of elevated carbon dioxide for soybean. Nature Plants 2, 16132.

Haworth M., Killi D., Materassi A., Raschi A., \& Centritto M. (2016) Impaired stomatal control is associated with reduced photosynthetic physiology in crop species grown at elevated $\left[\mathrm{CO}_{2}\right]$. Frontiers in Plant Science 7, 1568.

Leakey A. D., Ainsworth E. A., Bernacchi C. J., Zhu X., Long S. P., \& Ort D. R. (2012) Photosynthesis in a $\mathrm{CO}_{2}$-rich atmosphere. In: Photosynthesis (pp. 733-768). Springer Netherlands.

Nowak R.S., Ellsworth D.S., \& Smith S.D. (2004) Functional responses of plants to elevated atmospheric $\mathrm{CO}_{2}$ - do photosynthetic and productivity data from FACE experiments support early predictions? New phytologist 162, 253-280.

O'Leary G. J., Christy B., Nuttall J., Huth N., Cammarano,D., Stöckle C., ... \& FarreCodina I. (2015) Response of wheat growth, grain yield and water use to elevated 
$437 \mathrm{CO}_{2}$ under a Free-Air $\mathrm{CO}_{2}$ Enrichment (FACE) experiment and modelling in a semiarid environment. Global change biology 21, 2670-2686.

439 Outlaw Jr, W.H. (2003) Integration of cellular and physiological functions of guard cells. Critical Reviews in Plant Sciences 22, 503-529.

Parmesan C., \& Yohe G. (2003) A globally coherent fingerprint of climate change impacts across natural systems. Nature 421, 37-42.

Polley H. W., Tischler C. R., Johnson H. B., \& Pennington R. E. (1999) Growth, water relations, and survival of drought-exposed seedlings from six maternal families of honey mesquite (Prosopis glandulosa): responses to $\mathrm{CO}_{2}$ enrichment. Tree Physiology 19, 359-366.

Polley H.W., Johnson H.B., Fay P.A., \& Sanabria J. (2008) Initial response of evapotranspiration from tallgrass prairie vegetation to $\mathrm{CO}_{2}$ at subambient to elevated concentrations. Functional Ecology 22, 163-171.

Qaderi M. M., Kurepin L. V., \& Reid D. M. (2006) Growth and physiological responses of canola (Brassica napus) to three components of global climate change: temperature, carbon dioxide and drought. Physiologia Plantarum 128,710-721

Reekie E.G., MacDougall G., Wong I., \& Hicklenton P.R. (1998) Effect of sink size on growth response to elevated atmospheric $\mathrm{CO}_{2}$ within the genus Brassica. Canadian Journal of Botany 76, 829-835.

Ruiz-Vera U. M., Siebers M. H., Drag D. W., Ort D. R., \& Bernacchi C. J. (2015) Canopy warming caused photosynthetic acclimation and reduced seed yield in maize grown at ambient and elevated $\left[\mathrm{CO}_{2}\right]$. Global change biology 21, 4237-4249.

Vu J. C. V., Allen L. H., Boote K. J., \& Bowes G. (1997). Effects of elevated $\mathrm{CO}_{2}$ and temperature on photosynthesis and Rubisco in rice and soybean. Plant, Cell \& Environment 20, 68-76.

Wall G.W. (2001) Elevated atmospheric $\mathrm{CO}_{2}$ alleviates drought stress in wheat. Agriculture, ecosystems \& environment 87, 261-271.

Webster R. J., Driever S. M., Kromdijk J., McGrath J., Leakey A. D., Siebke K., ... \& Long S. P. (2016) High $\mathrm{C}_{3}$ photosynthetic capacity and high intrinsic water use efficiency underlies the high productivity of the bioenergy grass Arundo donax. Scientific reports, 6.

Xu Z., Shimizu H., Yagasaki Y., Ito S., Zheng Y., \& Zhou G. (2013) Interactive effects of elevated $\mathrm{CO}_{2}$, drought, and warming on plants. Journal of Plant Growth Regulation 32, 692-707. 

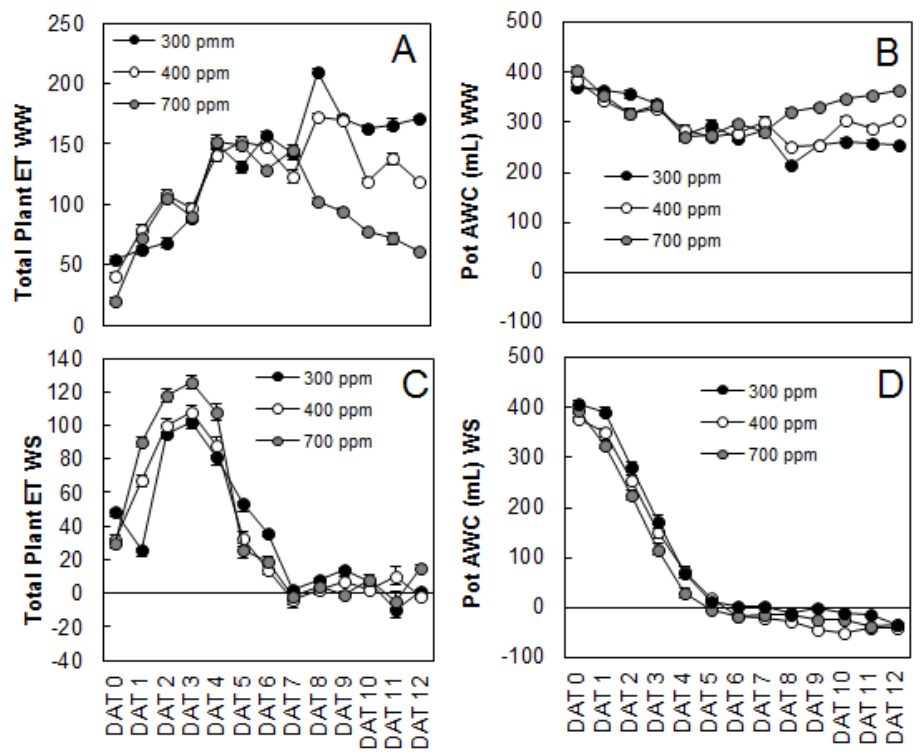

Figure 1. Development of daily total plant evapotranspiration (ET, $\mathrm{mL})$ under wellwatered (WW, A) and droughted conditions (WS, C) and development of pot available water content (AWC, $\mathrm{mL}$ ) under well-watered (WW, B) and droughted conditions (WS, D) of winter oilseed rape plants grown at historical (300 ppm), ambient $(400 \mathrm{ppm})$ and elevated $(700 \mathrm{ppm})$ atmospheric $\mathrm{CO}_{2}$ concentration. DAT= days after treatment application. Data were collected daily with a balance. Data are means $(n=6) \pm S E$. 

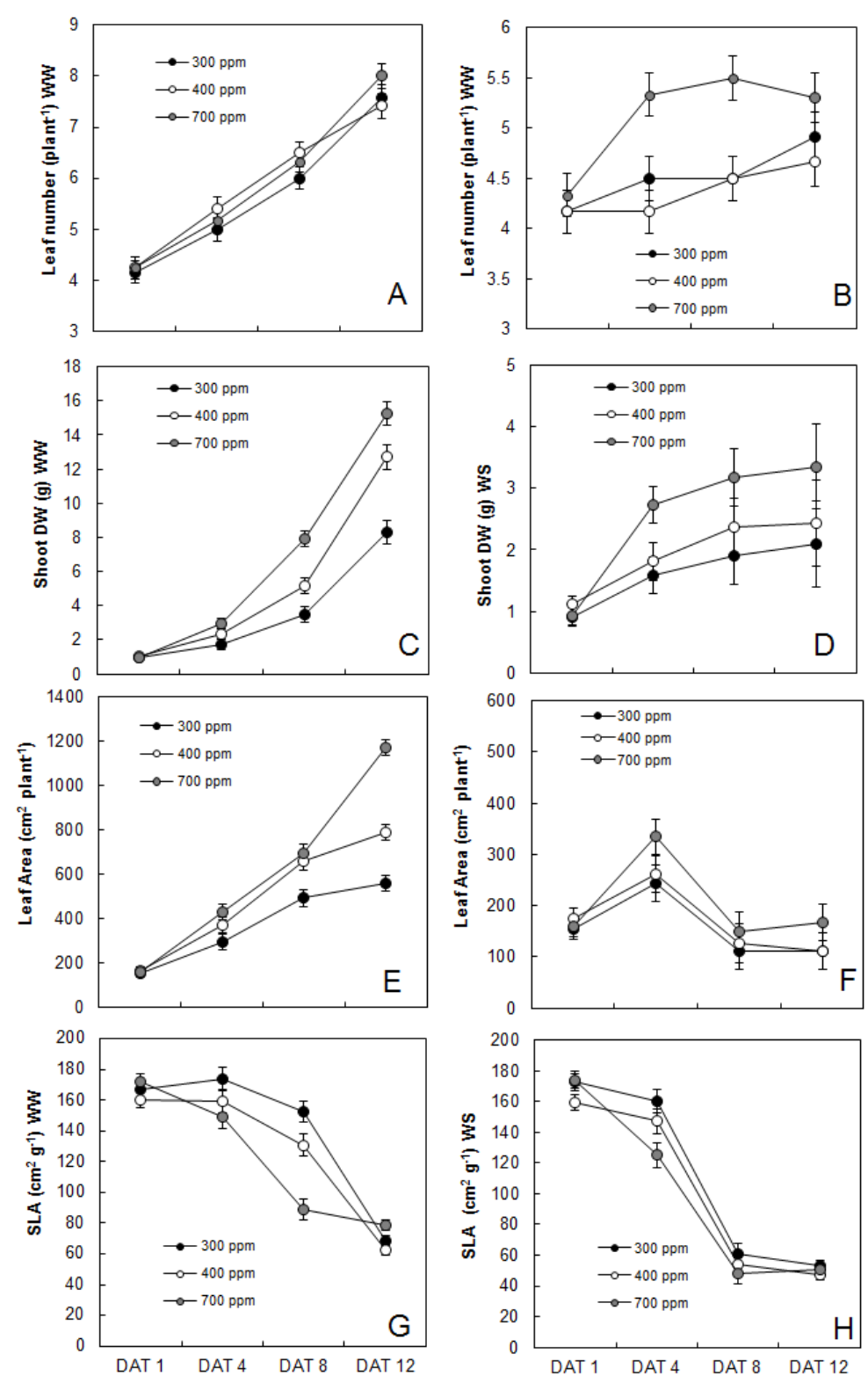

Figure 2. Development of leaf number (A, B), shoot dry weight (C, D; DW, g), total

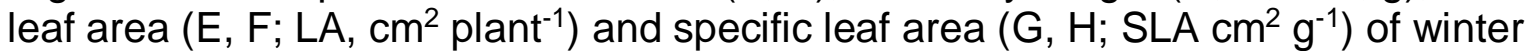
oilseed rape plants grown at historical (300 ppm), ambient (400 ppm) and elevated (700 ppm) atmospheric $\mathrm{CO}_{2}$ concentration under well-watered (WW; A, C, E, G) and water-stress (WS; B, D, F, H) conditions. Data were collected at days after treatment application (DAT) 1, 4, 8 and 12. Data are means 

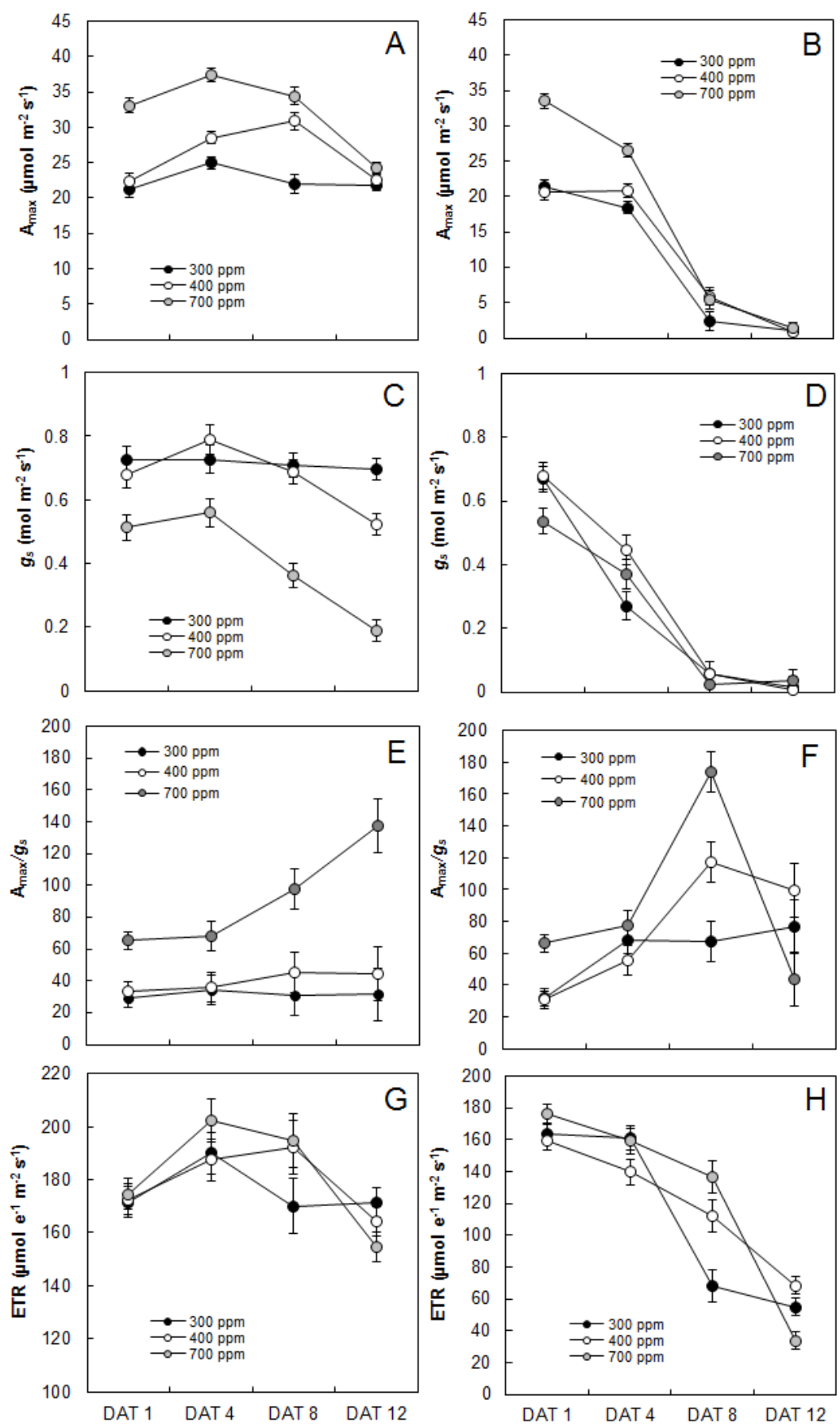

Figure 3. Development of carbon assimilation rate at saturating light $\left(A, B ; A_{\max }\right)$, stomatal conductance $\left(\mathrm{C}, \mathrm{D} ; g_{s}\right)$, intrinsic water-use efficiency $\left(\mathrm{E}, \mathrm{F} ; \mathrm{A}_{\max } / g_{s}\right)$ and electron transport rate $(\mathrm{G}, \mathrm{H}$; ETR) of winter oilseed rape plants grown at historical

(300 ppm), ambient (400 ppm) and elevated (700 ppm) atmospheric $\mathrm{CO}_{2}$ conditions. Data were collected at days after treatment application (DAT) 1, 4, 8 and 

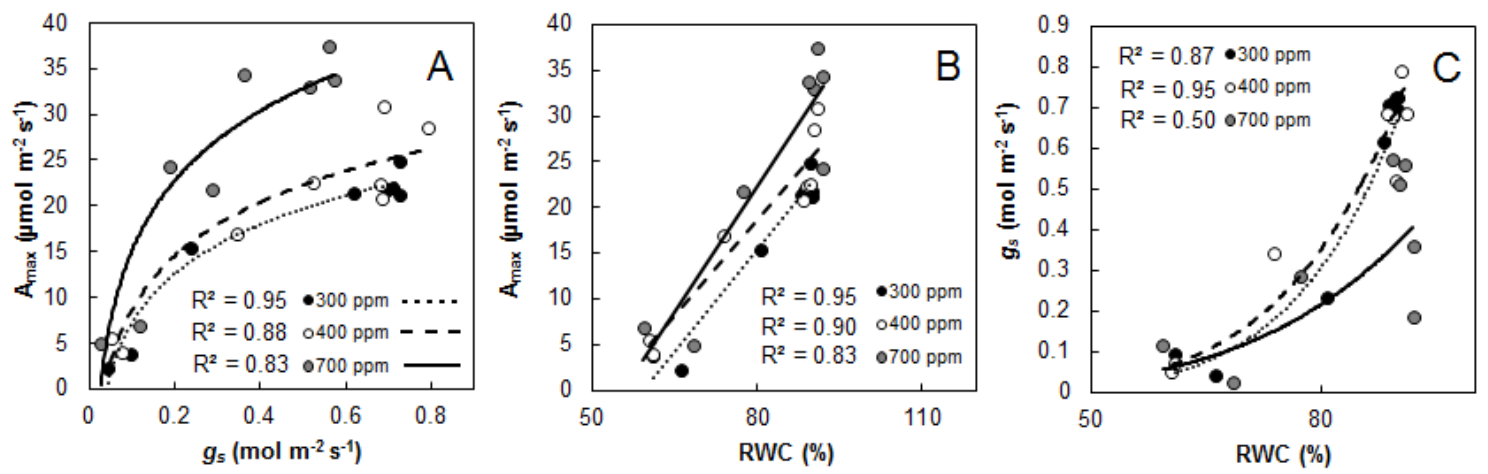

Figure 4. Correlations between $A) \mathrm{CO}_{2}$ assimilation rate at saturating light $\left(A_{\max }\right)$ and stomatal conductance $\left.\left(g_{s}\right), \mathrm{B}\right) \mathrm{A}_{\max }$ and leaf relative water content (RWC) and C) $g_{s}$ and RWC, of winter oilseed rape plants grown at 300 ppm (black symbols), 400 ppm (grey symbols) and 700 ppm white symbols) atmospheric $\mathrm{CO}_{2}$ concentration under well-watered (WW) and water-stress (WS) conditions Data points are means $(n=6)$. 


\begin{tabular}{|c|c|c|c|c|}
\hline \multirow[b]{2}{*}[\mathrm{CO}_{2}]{} & WW & WS & \multirow[b]{2}{*}{ ANOVA Factor } & \multirow[b]{2}{*}{$P$-values } \\
\hline & \multicolumn{2}{|c|}{ RWC (\%) DAT 1} & & \\
\hline 300 ppm & 89.9 & 88.9 & $\mathrm{CO}_{2}$ & 0.064 \\
\hline 400 ppm & 89.0 & 89.0 & Watering regimes & 0.802 \\
\hline \multirow[t]{2}{*}{700 ppm } & 90.1 & 90.0 & $\mathrm{CO}_{2} \times$ Watering regimes & 0.869 \\
\hline & \multicolumn{2}{|c|}{ RWC (\%) DAT 4} & & \\
\hline 300 ppm & 89.5 & 82.7 & $\mathrm{CO}_{2}$ & 0.182 \\
\hline 400 ppm & 90.2 & 76.6 & Watering regimes & $<.001^{*}$ \\
\hline \multirow[t]{2}{*}{700 ppm } & 90.8 & 81.6 & $\mathrm{CO}_{2} \times$ Watering regimes & 0.120 \\
\hline & \multicolumn{2}{|c|}{ RWC (\%) DAT 8} & & \\
\hline 300 ppm & 88.7 & 67.7 & $\mathrm{CO}_{2}$ & $0.016^{\star}$ \\
\hline 400 ppm & 90.9 & 61.9 & Watering regimes & $<.001^{*}$ \\
\hline \multirow[t]{2}{*}{700 ppm } & 91.8 & 69.2 & $\mathrm{CO}_{2} \times$ Watering regimes & $0.018^{*}$ \\
\hline & \multicolumn{2}{|c|}{ RWC (\%) DAT 12} & & \\
\hline 300 ppm & 89.9 & 56.2 & $\mathrm{CO}_{2}$ & 0.501 \\
\hline 400 ppm & 89.6 & 55.6 & Watering regimes & $<.001^{*}$ \\
\hline 700 ppm & 91.8 & 52.3 & $\mathrm{CO}_{2} \times$ Watering regimes & 0.065 \\
\hline
\end{tabular}

530

531 Table 1. Relative water content data (RWC,\%) of winter oilseed rape plants grown at historical (300 ppm), ambient (400 ppm) and elevated (700 ppm) atmospheric $\mathrm{CO}_{2}$ concentration under well-watered (WW) and water-stress (WS) conditions. Data 


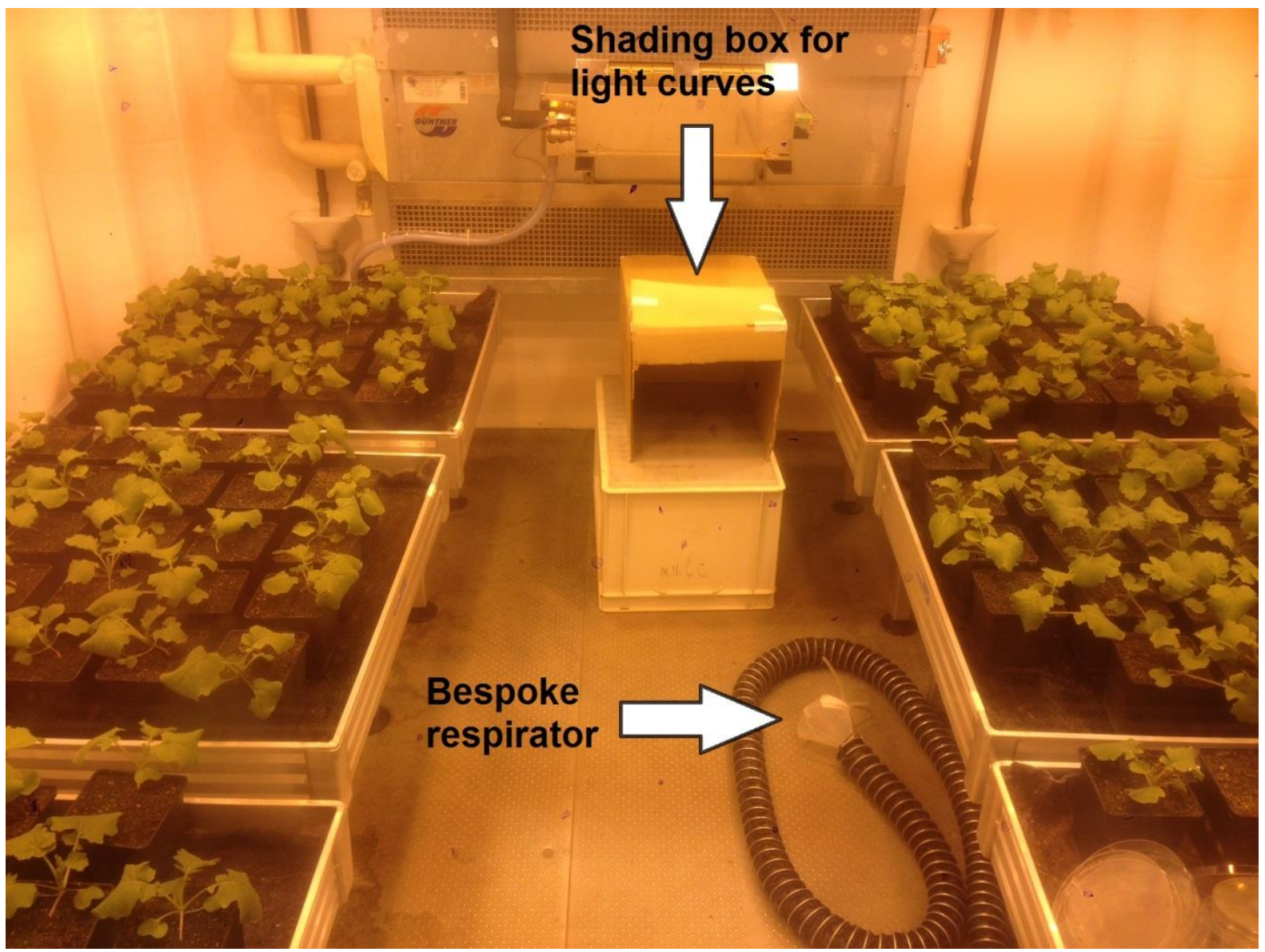

Supplementary Figure 1. Example of experimental room with the bespoke respirator and the cardboard box used to cover plants before the light curve protocol. 


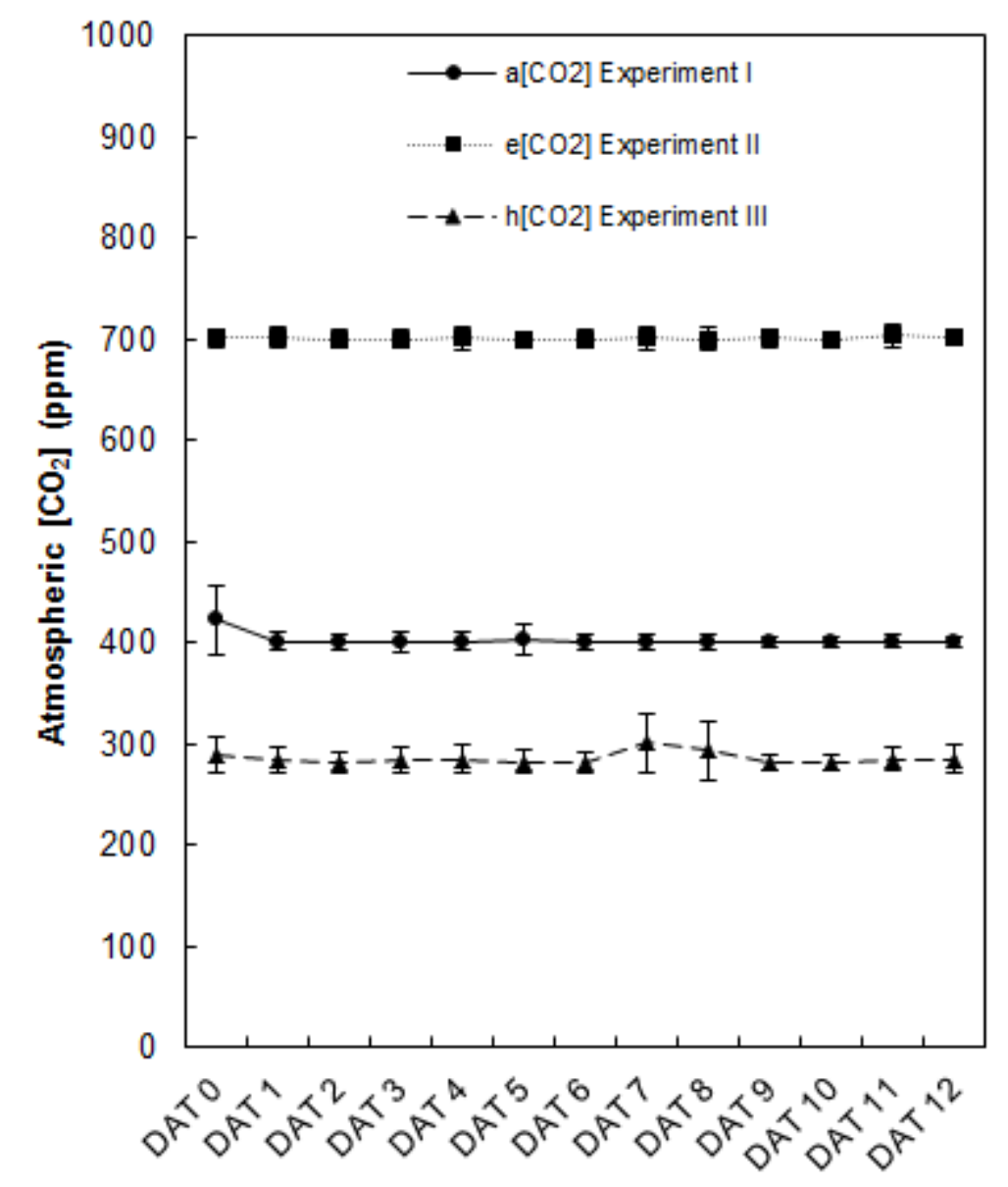

559

560 Supplementary Figure 2. Development of atmospheric $\left[\mathrm{CO}_{2}\right]$ over Experiment I $\left(\mathrm{a}\left[\mathrm{CO}_{2}\right]\right)$, Experiment II $\left(\mathrm{e}_{\mathrm{e}}\left[\mathrm{CO}_{2}\right]\right)$ and Experiment II $\left(\mathrm{h}\left[\mathrm{CO}_{2}\right]\right)$. Data points are means $(n=1440) \pm$ standard deviation (SD). 


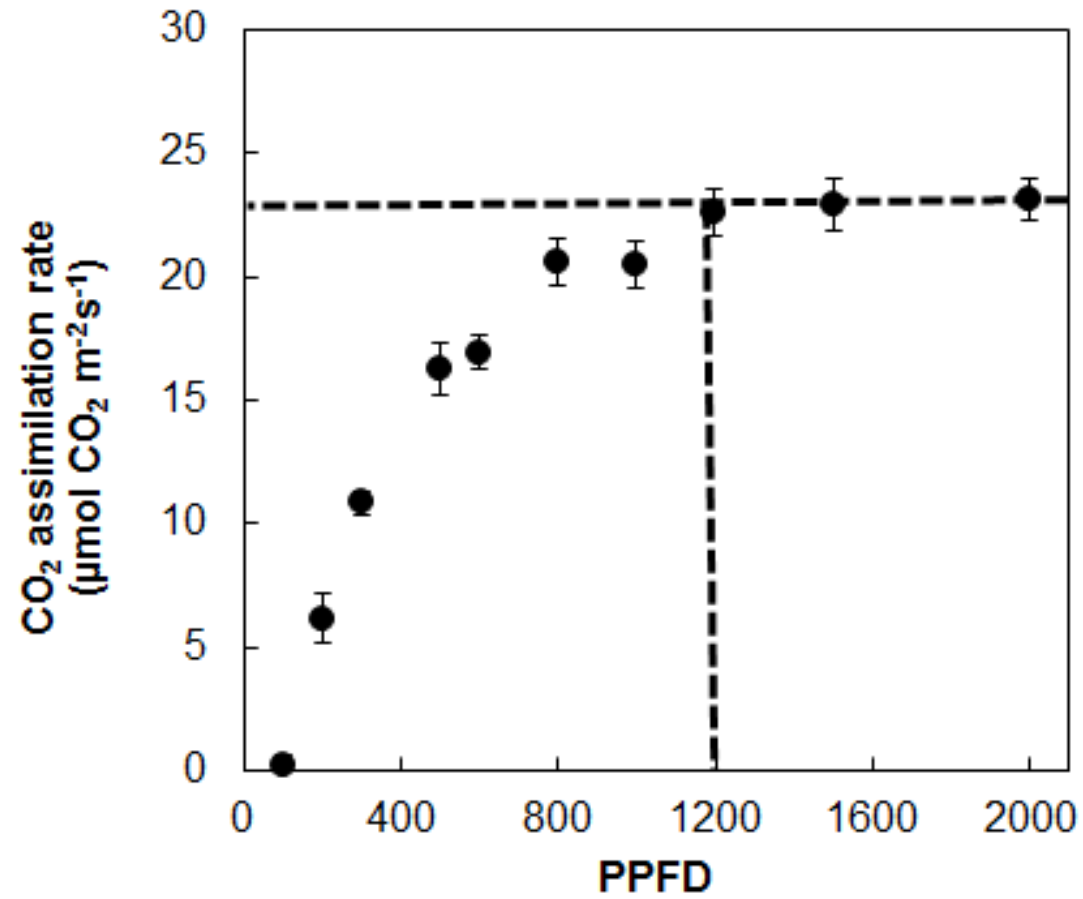

Supplementary Figure 3. Light-response curves for oilseed rape seedlings. The curves were plotted on the third fully expanded leaf before Experiment I. A Li-Cor 6400 was used supplemented with a LI-6400-40 cuvette. $\mathrm{CO}_{2}$ assimilation rates were collected at 100, 200, 300, 500, 600, 800, 1000, 1200, 1500 and 2000 PPFD. Cuvette temperature was maintained at $25^{\circ} \mathrm{C}$, the flow rate was $300 \mu \mathrm{mol} \mathrm{s}{ }^{-1}, \mathrm{CO}_{2}$ $\left(\mathrm{C}_{\mathrm{a}}\right)$ was $400 \mathrm{ppm}$ and the light source was maintained at 10:90 blue-red light. Data points are means \pm SEM $(n=6)$ with the exception of 200,500 and 800 PPFD where 
Supplementary Figure 4. Analysis of variance ( $P$-values) for $\left[\mathrm{CO}_{2}\right]$, watering regimes and their interactive effects on plant dry-weight (shoot DW), Leaf area, Leaf number, Specific Leaf Area, $\mathrm{CO}_{2}$ assimilation rate at saturating light $\left(\mathrm{A}_{\max }\right)$, stomatal conductance $\left(g_{s}\right)$ and water use efficiency $\left(\mathrm{A}_{\max } / g_{s}\right)$ of winter oilseed rape plants grown at 300ppm, 400ppm and 700ppm atmospheric $\mathrm{CO}_{2}$ concentration under well-watered (WW) and water-stress (WS) conditions. Values significance is highlighted with asterisks $(P<0.05)$

\begin{tabular}{|c|c|c|c|c|}
\hline \multirow[b]{3}{*}{ ANOVA Factor } & \multicolumn{4}{|c|}{ Shoot DW } \\
\hline & $\overline{\text { DAT } 1}$ & DAT 4 & DAT 8 & $\overline{\text { DAT } 12}$ \\
\hline & \multicolumn{4}{|c|}{$P$-values } \\
\hline$\overline{\mathrm{CO}_{2}}$ & 0.219 & $<.001^{*}$ & $<.001^{*}$ & $<.001^{*}$ \\
\hline Watering regimes & 0.662 & 0.053 & $<.001^{*}$ & $<.001^{*}$ \\
\hline \multirow[t]{3}{*}{$\mathrm{CO}_{2} \times$ Watering regimes } & 0.829 & 0.358 & $<.001^{*}$ & $<.001^{*}$ \\
\hline & \multicolumn{4}{|c|}{ Leaf Area } \\
\hline & DAT 1 & DAT 4 & DAT 8 & DAT 12 \\
\hline ANOVA Factor & \multicolumn{4}{|c|}{$P$-values } \\
\hline $\mathrm{CO}_{2}$ & 0.333 & $<.001^{*}$ & $<.001^{*}$ & $<.001^{*}$ \\
\hline Watering regimes & 0.367 & $<.001^{*}$ & $<.001^{*}$ & $<.001^{*}$ \\
\hline \multirow[t]{3}{*}{$\mathrm{CO}_{2} \times$ Watering regimes } & 0.953 & 0.052 & $0.001^{*}$ & $<.001^{*}$ \\
\hline & \multicolumn{4}{|c|}{ Leaf number } \\
\hline & DAT 1 & DAT 4 & DAT 8 & DAT 12 \\
\hline ANOVA Factor & \multicolumn{4}{|c|}{$P$-values } \\
\hline $\mathrm{CO}_{2}$ & 0.232 & $<.001$ & $<.001^{*}$ & $<.001^{*}$ \\
\hline Watering regimes & 1 & $0.016^{*}$ & $<.001^{*}$ & $<.001^{*}$ \\
\hline \multirow[t]{3}{*}{$\mathrm{CO}_{2} \times$ Watering regimes } & 0.929 & 0.097 & $0.005^{*}$ & 0.066 \\
\hline & \multicolumn{4}{|c|}{ Specific Leaf Area } \\
\hline & DAT 1 & DAT 4 & DAT 8 & DAT 12 \\
\hline ANOVA Factor & \multicolumn{4}{|c|}{$P$-values } \\
\hline $\mathrm{CO}_{2}$ & 0.15 & $<.001^{*}$ & $<.001^{*}$ & $<.001^{*}$ \\
\hline Watering regimes & 0.302 & $0.003^{*}$ & $<.001^{*}$ & $<.001^{*}$ \\
\hline \multirow[t]{3}{*}{$\mathrm{CO}_{2} \times$ Watering regimes } & 0.682 & 0.277 & $<.001^{*}$ & 0.45 \\
\hline & \multicolumn{4}{|c|}{$\overline{A_{\max }}$} \\
\hline & DAT 1 & DAT 4 & DAT 8 & DAT 12 \\
\hline ANOVA Factor & \multicolumn{4}{|c|}{$P$-values } \\
\hline $\mathrm{CO}_{2}$ & $<.001^{*}$ & $<.001^{*}$ & $<.001^{*}$ & $0.008^{*}$ \\
\hline Watering regimes & 0.445 & $<.001^{*}$ & $<.001^{*}$ & $<.001^{*}$ \\
\hline \multirow[t]{3}{*}{$\mathrm{CO}_{2} \times$ Watering regimes } & $0.043^{*}$ & 0.063 & $<.001^{*}$ & 0.071 \\
\hline & \multicolumn{4}{|c|}{$g_{s}$} \\
\hline & DAT 1 & DAT 4 & DAT 8 & DAT 12 \\
\hline ANOVA Factor & \multicolumn{4}{|c|}{$P$-values } \\
\hline $\mathrm{CO}_{2}$ & $<.001^{*}$ & $<.001^{*}$ & $<.001^{*}$ & $<.001^{*}$ \\
\hline Watering regimes & 0.254 & $<.001^{*}$ & $<.001^{*}$ & $<.001^{*}$ \\
\hline \multirow[t]{4}{*}{$\mathrm{CO}_{2} \times$ Watering regimes } & 0.71 & $<.001^{*}$ & $<.001^{*}$ & $<.001^{*}$ \\
\hline & \multicolumn{4}{|c|}{$A_{\max } / g_{s}$} \\
\hline & DAT 1 & DAT 4 & DAT 8 & DAT 12 \\
\hline & \multicolumn{4}{|c|}{$P$-values } \\
\hline $\mathrm{CO}_{2}$ & $<.001^{*}$ & $<.001^{*}$ & $<.001^{*}$ & $<.001^{*}$ \\
\hline Watering regimes & 0.505 & $<.001^{*}$ & $<.001^{*}$ & 0.956 \\
\hline $\mathrm{CO}_{2} \times$ Watering regimes & 0.536 & 0.062 & $0.003^{*}$ & $<.001^{*}$ \\
\hline
\end{tabular}

